\title{
TEACHER PERCEPTION ON LEADERSHIPS: SURVEY ON PUBLIC HIGH SCHOOLS IN BANDUNG REGENCY
}

\author{
Vicky Achmad Zulfikar1, Robbi Saepul Rahman², Nita Yura Roslina \\ 1,2,3 Sekolah Tinggi Ilmu Ekonomi, Pasundan, Bandung, Indonesia. \\ E-mail: vicky@stiepas.ac.id ${ }^{1}$, robbi@stiepas.ac.id², nita@stiepas.ac.id ${ }^{3}$
}

\begin{abstract}
The leadership role of the principal is one aspect in improving the quality of education. Principal leadership consists of various components, namely leadership styles, educators, managers, administrators, supervisors, leaders, innovators and motivators. This study aims to validate the components proposed in this study whether they are the forming factors of the principal's leadership variable. To answer the research questions, the researchers used a quantitative approach with factor analysis techniques to validate the predetermined components perceived by the teacher. Respondents are high school teachers at one of the secondary schools in Bandung Regency as many as 75 teachers. The results indicate that it is evident that the principal's leadership consists of 8 components, namely leadership style, educator, manager, administrator, supervisor, leader, innovator and motivator. The results of the study indicate that the principal's measurement can use the 8 factors that make up the principal's leadership variable.
\end{abstract}

Keywords: leadership, principal, teacher, secondary school.

\section{INTRODUCTION}

The low quality of human resources is a fundamental problem that can hinder the development and development of the national economy. (Stankevičiūtè \& Savanevičienè, 2018) Structuring human resources needs to be pursued gradually and continuously through a quality education system in formal, informal, and non-formal education, starting from primary education to higher education. (Brewer \& Brewer, 2010)

The role of professional educators is needed to realize the goals of national education, namely to educate the nation's life and develop a complete human being. (DarlingHammond, Hyler \& Gardner, 2017). The existence of teachers is crucial for a nation, especially the survival of the nation with increasingly higher technology and all its roles and abilities. (Maguire, 2014). Concerning positions and professions, the phenomenon sees in certificates or diplomas and deeds following the subjects taught. This phenomenon 
becomes very influential on teachers' performance, both in learning and in the classroom and on the expected results of students. Likewise for making lesson plans less than optimal. (Powell \& Bodur, 2019) This condition is undoubtedly very concerning for the world of education in general. Currently, the government is trying to improve the quality of education, considering the growing demands of education in the world of education, which are getting heavier, especially in the mastery of science and technology and ethics. This problem is fundamental in connection with the development of science and technology, which brings changes in almost all aspects of human life. The answer to all of that is the mastery and improvement of science and technology. (Jabbour \& Santos, 2008) In addition to this, the government improves quality, but quantity is also significant so that the enrollment rate of children in school will be higher. The mastery of skills and knowledge about maximum teacher training absolutely must be owned by the teacher. (Abubakar, 2018)

Professional school principals must always be creative and productive in carrying out educational innovations to improve the quality of education. (Goddard, Skrla \& Salloum, 2017) However, preparing innovative principals is a challenging obstacle if associated with the welfare system for the existing teacher staff, which is far from adequate. (Ingersoll, Sirinides \& Dougherty, 2018)

To improve the professionalism of principals in schools in educational institutions, need some effort to increase work creativity, work motivation, performance, and work productivity of principals and provide various types, forms of training, professional education, and various other professional activities for principals. However, government policies are also needed to develop human resources through the professionalization of educators and education personnel to improve the quality of school principals and educators. Professional principals generally always show high work motivation in carrying out daily professional tasks at school. (Neumerski, Grissom, Goldring, Rubin, Cannata, Schuermann \& Drake, 2018).

The government has determined that school principals must carry out their work as educators, managers; administrators; and supervisors. In further developments, needs of the community, and the times, the principal must also act as a leader, innovator, and motivator in his school. Thus in the new paradigm of education management, principals must at least function as educators, managers, administrators, supervisors, leaders, innovators, motivators.

\section{METHOD}

The research method used in this research is the quantitative analysis method. The research carries at one of the public junior high schools in Bandung Regency with 75 teachers as respondents.

The operations of this research include the principal's leadership variable. The researcher wants to test whether the principal variable component is a constituent of the 
principal's leadership variable based on the teacher's perception. This component includes leadership styles, educators, managers, administrators, supervisors, leaders, innovators, and motivators.

To determine the components that make up the researcher using a factor analysis approach to determine how many factors will form as the principal leadership variable. Before testing, the researcher first tested the validity and reliability of the research instrument.

\section{RESULTS AND DISCUSSION}

Characteristics of respondents known that the age category of respondents dominated between 31 to 40 years, namely $37 \%$, then the age range above 50 years is $33.3 \%$, then the age of 41 between 50 years as much as $22.2 \%$ and the least age is under 30 years as much as $7.4 \%$. Respondents by sex knew that the majority of respondents who became the study population were male. While respondents based on education categories can see that the majority of respondents have an education level of S1.

After testing the validity and reliability of the research instrument, the researcher conducted a factor analysis test to find out how many factors formed the principal's leadership variable. The results of the calculation of validity and reliability are as follows:

Table 1. Results of the validity and reliability of research instruments

\begin{tabular}{|l|c|}
\hline \multicolumn{1}{|c|}{ Item } & Result \\
\hline item1 & 0,50 \\
item2 & 0,59 \\
item3 & 0,51 \\
item4 & 0,45 \\
item5 & 0,64 \\
item6 & 0,65 \\
item7 & 0,43 \\
item8 & 0,76 \\
item9 & 0,58 \\
item10 & 0,59 \\
item11 & 0,76 \\
item12 & 0,58 \\
item13 & 0,65 \\
item14 & 0,58 \\
item15 & 0,68 \\
item16 & 0,58 \\
item17 & 0,70 \\
item18 & 0,38 \\
item19 & 0,45 \\
item20 & 0,60 \\
item21 & 0,50 \\
item22 & 0,68 \\
\hline
\end{tabular}




\begin{tabular}{|l|l|}
\hline item23 & 0,81 \\
item24 & 0,56 \\
item25 & 0,46 \\
\hline Cronbach's Alpha & 0,92 \\
\hline
\end{tabular}

The results of the calculation of validity and reliability indicate that the research instrument is valid. The correlation results are above 0.3 and reliable with a value of 0.92 , above the number 0.7 as required. Thus the calculation of data analysis can be continued with factor analysis.

The calculation of factor analysis shows that the Kaiser-Meyer-Olkin Measure value is 0.753 with a significant Bartlett's Test of Sphericity 0.000 . The communalities values present in table 2 below:

Table 2. Communality values and extraction variance

\begin{tabular}{|l|c|c|c|c|}
\hline Item & Extraction & Factor & \% of Variance & Cumulative \% \\
\hline item1 & .696 & 1 & 31.589 & 31.589 \\
item2 & .624 & 2 & 6.935 & 38.525 \\
item3 & .470 & 3 & 5.982 & 44.506 \\
item4 & .369 & 4 & 5.674 & 50.181 \\
item5 & .357 & 5 & 4.217 & 54.398 \\
item6 & .989 & 6 & 3.575 & 57.973 \\
item7 & .915 & 7 & 2.866 & 60.839 \\
item8 & .719 & 8 & 2.697 & 6 \\
item9 & .736 & & & \\
item10 & .450 & & & \\
item11 & .803 & & & \\
item12 & .465 & & & \\
item13 & .748 & & & \\
item14 & .430 & & & \\
item15 & .566 & & & \\
item16 & .413 & & & \\
item17 & .795 & & & \\
item18 & .713 & & & \\
item19 & .532 & & & \\
item20 & .525 & & & \\
item21 & .669 & & & \\
item22 & .605 & & & \\
item23 & .845 & & & \\
item24 & & & & \\
item25 & & & & \\
\hline
\end{tabular}

The results of the extraction of the research instrument showed a value above 0.3. Therefore, it can say that the statement item can represent the variation in the meaning of the research instrument. Furthermore, the calculation results can see several factors that will form as described in table 2 as presented previously. 
The results of the variation of the research instrument show that there are eight factors formed from 25 statement items with a total value of the variation of $63.54 \%$. Therefore, the calculation results indicate that $63.54 \%$ of the items can explain the research variables. Furthermore, the results of the component matrix can see in table 3 below.

Table 3. The results of the factorial research instrument.

\begin{tabular}{|l|c|c|c|c|c|c|c|c|}
\hline \multirow{2}{*}{ Item } & \multicolumn{7}{|c|}{ Factor } \\
\cline { 2 - 8 } & 1 & 2 & 3 & 4 & 5 & 6 & 7 & 8 \\
\hline item17 & .750 & & -.128 & & & & -.438 & -.119 \\
item9 & .729 & -.205 & .244 & & -.182 & & -.110 & .240 \\
item23 & .682 & .169 & & & & -.112 & -.182 & -.266 \\
item6 & .663 & .148 & -.161 & -.412 & & -.566 & .105 & \\
item11 & .646 & & -.254 & .402 & -.288 & & .103 & -.234 \\
item22 & .642 & -.240 & -.110 & -.226 & -.251 & & & \\
item25 & .637 & -.424 & .484 & & & & & \\
item8 & .630 & & -.344 & .186 & -.196 & .297 & .185 & \\
item1 & .615 & -.438 & .264 & & & -.188 & .101 & \\
item15 & .607 & -.138 & & -.106 & -.236 & .257 & -.136 & .152 \\
item14 & .547 & .148 & & & & .304 & & \\
item12 & .542 & -.154 & -.223 & -.146 & & & -.103 & -.257 \\
item2 & .529 & & .356 & -.301 & & .192 & -.209 & .177 \\
item20 & .523 & -.142 & -.167 & .368 & -.107 & & .138 & .188 \\
item16 & .521 & -.236 & & & -.120 & & .239 & \\
item5 & .500 & .109 & & & .182 & & .198 & -.118 \\
item3 & .491 & .311 & & -.236 & .189 & & .144 & -.106 \\
item18 & .482 & -.139 & -.474 & & .366 & -.259 & & .166 \\
item10 & .468 & .246 & & -.253 & .152 & & & -.275 \\
item4 & .442 & -.196 & .156 & .103 & .305 & & & \\
item19 & .437 & -.112 & .399 & .153 & .248 & & .240 & -.160 \\
item21 & .343 & .597 & .351 & .181 & .103 & & -.161 & \\
item13 & .450 & .463 & & -.367 & -.188 & & .292 & .274 \\
item7 & .407 & .487 & .146 & .624 & & -.290 & & .120 \\
item24 & .536 & & -.346 & & .553 & .237 & & .244 \\
\hline
\end{tabular}

The calculation results indicate that the principal's leadership forms the variable component into eight factors with a total variation of $63.53 \%$. Following the research and data processing results, it proves that the leadership component form from eight factors. Furthermore, it knows that the principal's leadership has implemented leadership criteria which include: a democratic leadership style, the principal as an educator, the principal as a manager, the principal as an administrator, the principal as a supervisor, the principal as a leader, the principal as an innovator and the principal as a motivator. The principal's leadership is excellent because the principal can lead the school to motivate teachers and education staff to improve the quality of education. The principal's leadership can function as an educator, manager, administrator, supervisor, leader, innovator, motivator. The principal plays a significant role in moving or coloring the wheel of the organization (school). The principal's leadership can carry out his duties properly will affect the 
teacher's performance. Moreover, principals who can implement it will improve teacher performance and improve the quality of education. The results of this study are in line with research conducted by Neumerski, Grissom, Goldring, Rubin, Cannata, Schuermann \& Drake (2018) and Ingersoll, Sirinides \& Dougherty (2018), which show the critical role of school principals in increasing the effectiveness of learning in schools.

\section{CONCLUSION}

Based on testing the validity and reliability, it knows that all research items are proven to be valid and reliable. Furthermore, the calculation results of factor analysis also prove that the principal's leadership consists of 8 factors: leadership styles, educators, managers, administrators, supervisors, leaders, innovators, and motivators. Therefore, it can indicate that the principal's leadership could be measured using these components described in the discussion. However, further testing is still needed to make this component a form of principal leadership. The drawback of this study is that it only uses respondents from high school teachers; further research recommends conducting testing using a sample of teachers at the elementary and high school levels to know more general results.

\section{REFERENCES}

Abubakar, A. (2018). The role of educational supervisors towards improving teachers performance. Bauchi State University, February, 0-14.

Brewer, P. D., \& Brewer, K. L. (2010). Knowledge management, human resource management, and higher education: A theoretical model. Journal of Education for Business, 85(6), 330-335.

Darling-Hammond, L., Hyler, M. E., \& Gardner, M. (2017). Effective teacher professional development. Learning Policy Institute.

Goddard, R. D., Skrla, L., \& Salloum, S. J. (2017). The role of collective efficacy in closing student achievement gaps: A mixed methods study of school leadership for excellence and equity. Journal of education for students placed at risk (JESPAR), 22(4), 220-236.

Ingersoll, R. M., Sirinides, P., \& Dougherty, P. (2018). Leadership Matters: Teachers' Roles in School Decision Making and School Performance. American Educator, 42(1), 13.

Jabbour, C. J. C., \& Santos, F. C. A. (2008). The central role of human resource management in the search for sustainable organizations. The International Journal of Human Resource Management, 19(12), 2133-2154. 
Maguire, M. (2014). Reforming teacher education in England:'an economy of discourses of truth'. Journal of Education Policy, 29(6), 774-784.

Neumerski, C. M., Grissom, J. A., Goldring, E., Rubin, M., Cannata, M., Schuermann, P., \& Drake, T. A. (2018). Restructuring instructional leadership: How multiplemeasure teacher evaluation systems are redefining the role of the school principal. The Elementary School Journal, 119(2), 270-297.

Powell, C. G., \& Bodur, Y. (2019). Teachers' perceptions of an online professional development experience: Implications for a design and implementation framework. Teaching and Teacher Education, 77, 19-30.

Stankevičiūtè, Ž., \& Savanevičienè, A. (2018). Designing sustainable HRM: The core characteristics of emerging field. Sustainability, 10(12), 4798. https://doi.org/10.3390/su10124798 